Dergi Ana Sayfası: https://dergipark.org.tr/tr/pub/ahbvtfd

ISSN: $2687-1912$

DOI: $10.34189 / \mathrm{tfd} .23 .02 .008$

\title{
Turistlerin Rasyonel ve Duygusal Deneyimlerinin Belirlenmesine Yönelik Bir Araştırma: Kapadokya Örneği
}

(A Research on Determining Rational and Emotional Experiences of Tourists: The Case of Cappadocia)

\author{
* Aydın ÜNAL ${ }^{\mathrm{a}}$ \\ ${ }^{a}$ Kırklareli Üniversitesi, Pınarhisar Meslek Yüksekokulu, Turizm ve Seyahat Hizmetleri Programı, Kırklareli-Türkiye \\ (aydin.unal@klu.edu.tr) https://orcid.org/0000-0002-6377-8587
}

MAKALE GEÇMIş̧i

Gönderim Tarihi:

23.09.2020

Kabul Tarihi:

05.10 .2020

\section{Anahtar Kelimeler:}

Rasyonel Deneyim

Duygusal Deneyim

Deneyimsel Pazarlama

Destinasyon Pazarlaması

Kapadokya

\section{Keywords: \\ Rational Experince \\ Emotional Experinece \\ Experiential Marketing \\ Destination Marketing \\ Kapadokya}

Makalenin Türü: Araştırma Makalesi

*Sorumlu Yazar: Aydın ÜNAL

E posta: aydin.unal@klu.edu.tr
$\ddot{O} \mathbf{Z}$

Geleneksel pazarlama anlayışını benimseyen destinasyonlar turistlere sahip oldukları çekicilikleri sunmakla kendilerini sınırlandırmaktadırlar. $\mathrm{Bu}$ anlayışta turistler destinasyonlardaki turistik çekicilikleri sadece izlemekle ve fotoğraflamakla yetinmektedirler. $\mathrm{Bu}$ durum turistlerin pasif kalmasına ve destinasyonlardaki turistik çekiciliklerle bütünleşememelerine neden olmaktadır. Çağdaş pazarlama yaklaşımlarından deneyimsel pazarlama anlayışını benimseyen destinasyonlarda ise turistlerin aktif hale getirilmesi ve destinasyonların turistik çekiciliklerini deneyimlemeleri esas alınmaktadır. Bu çalışmada Kapadokya destinasyonunu ziyaret eden yerli turistlerin algıladıkları rasyonel ve duygusal deneyim boyutlarının belirlenmesi amaçlanmaktadır. Bu amaçla Kapadokya destinasyonunda tatillerini geçirmekte olan yerli turistlere kendilerinin cevaplandırdıkları toplam 260 anket formu 1 Mayıs-30 Kasım 2018 tarih aralığında yüz yüze iletişim kurularak ulaştırılmıştır. Geri dönüş sağlanan anket formlarından 20 tanesi anket formlarındaki cevap seçeneklerinin \%50'sinden fazlasının doldurulmamasından veya aynı cevap seçeneğinin birden fazla kez doldurulmasından dolayı değerlendirme dışında bırakılmıştır. Değerlendirmeye alınan 240 anket formundan elde edilen veriler SPSS istatistiki veri analiz programı ile değerlendirilmişlerdir. Yapılan analizler neticesinde; yerli turistlerin çoğunluğunun destinasyondan genel olarak memnun kaldıkları (\%81) ve destinasyonu tekrar ziyaret etme niyetinde (\%74) oldukları belirlenmiştir. Ayrıca yerli turistlerin destinasyon rasyonel ve duygusal deneyim boyutlarının belirlenmesine yönelik uygulanan açıklayıcı faktör analizi sonuçlarına göre turistlerin rasyonel deneyim boyutları seyahat öncesi hazırlık deneyimi, destinasyonda yaşanan deneyim ve öğrenme deneyimi; duygusal deneyim boyutları ise eğlence deneyimi, kaçış deneyimi ve estetik deneyimi olarak adlandırılmıştır.

\section{ABSTRACT}

Destinations that embrace the traditional understanding of marketing limit themselves to offering tourists the charms they have. In this sense, tourists are content with watching and photographing the tourist attractions in the destinations. This causes tourists to remain passive and not to be able to integrate with tourist attractions in destinations. On the other hand, in destinations that embrace the experiential marketing approach which is one of the modern marketing approaches, it is essential to activate the tourists and to make them experience the tourist attractions of the destinations. In this research, it is aimed to determine the rational and emotional experience dimensions perceived by domestic tourists visiting the Cappadocia destination. For this purpose, a total of 260 questionnaires were delivered to the domestic tourists who were at 1 May-30 November 2018 in spending their holidays in Cappadocia by face-to-face communication. Twenty of the returned questionnaire forms were excluded from the evaluation since more than $50 \%$ of the answer options were left blank or the same answer option was coded more than once. The data obtained from 240 questionnaires were evaluated by use of SPSS statistical data analysis program. As a result of the analyzes, it was found that the (\%74) majority of the domestic tourists $(81 \%)$ were satisfied with the destination in general and intended to revisit the destination. In addition, according to the results of the explanatory factor analysis applied to determine the rational and emotional experience dimensions of the domestic tourists, the rational experience dimensions of the tourists were called pre-travel preparation experience, experience in the destination and learning experience; and the dimensions of emotional experience were called entertainment experience, escape experience and aesthetic experience.

Makalenin Künyesi: Ünal, A. (2020). Turistlerin Rasyonel ve Duygusal Deneyimlerinin Belirlenmesine Yönelik Bir

Araştırma: Kapadokya Örneği. AHBVÜ Turizm Fakültesi Dergisi, 23 (2), 374-393 


\section{KAVRAMSAL ÇERÇEVE}

Türk Dil Kurumu (TDK) Güncel Türkçe Sözlügünde “destinasyon” kavramı "varılacak yer” olarak tanımlanmaktadır (TDK, 2020). Ancak konaklama, ulaşım, yeme içme, eğlence ve rekreasyon gibi ticari turistik hizmetler ile manzara, orman ve yerel halk gibi ticari olmayan deneyimlerin ve turist algıları gibi unsurların bileşiminden oluşan destinasyon kavramını (Hall, 2000; Crouch, 2000: 68) bu sade tanımla tamamen açıklamak mümkün değildir. $\mathrm{Bu}$ sebeple yerli ve yabancı literatürde destinasyon kavramı ile ilgili yapılmış çok sayıda tanıma rastlamak mümkündür. Coltman (1989) destinasyonu; "farklı doğal özellikleri ve çekicilikleri olan ve turistlerin ilgisini çeken coğrafik alanlar”; Tosun ve Jenkins (1996) destinasyonu; “ülke bütününden küçük veya ülke içindeki birçok kentten daha büyük ve insanlarda belli bir imaja sahip markalaşmış ulusal bir alan" ve Frisk (1999) destinasyonu; "sıradan yerel halk içerisinde turistik bir toplum oluşturulabilen coğrafik bir bölge veya yerel bir alan” olarak tanımlamaktadırlar.

Geleneksel olarak destinasyonlar bir kasaba, bir ada veya bir ülke gibi kesin bir şekilde tanımlanmış fiziksel sınırları olan coğrafik alanlar olarak tanımlanmaktadırlar. Ancak güncel destinasyon tanımlarında kavramın algısal yönüne dikkat çekilmektedir ve turistlerin geçmiş deneyimleri, eğitim seviyeleri, seyahat amaçları, kültürel birikimleri ve seyahat motivasyonlarına bağlı öznel değerlendirmeleri temelinde kavram yorumlanmaktadır. Örneğin; Alman bir iş insanı için toplantı amaçlı ziyaret ettiği Londra kenti bir destinasyon olarak algılanırken iki haftalık altı Avrupa ülkesini kapsayan bir paket turda boş zamanını değerlendirmek amaçlı tur satın almış bir Japon turist için paket turun kapsamındaki altı ülkenin bütünü bir destinasyon olarak algılanmaktadır. Destinasyon kavramı ile ilgili olarak coğrafik ve politik sınırlar temelinde yapılacak kısıtlamalar da turizm sektörünün fonksiyonlarını ve turistlerin tercihlerini anlamada hatalara neden olabilmektedir. Örneğin; Alpler coğrafik ve politik olarak Fransa, Avusturya, İsviçre ve İtalya ülkelerinin sınırları içerisinde yer almasına rağmen destinasyonu ziyaret eden kayakçılar tarafından tek bir destinasyon olarak algılanıp değerlendirilmektedir (Buhalis, 2000: 97-98). Çakıcı ve Aksu (2007) destinasyonu turistik deneyim yaşamaya imkân verecek şekilde arz olanaklarının bir araya geldiği bölgeler olarak tanımlamaktadırlar. Turistler seyahatlerinde tek bir ürünü almaktan veya tek bir deneyim yaşamaktan ziyade çeşitli ürünlerin ve hizmetlerin bileşimini deneyim etmek isterler. Bir destinasyonun turistler tarafından çekim yeri olarak algılanabilmesi için doğal, kültürel, tarihi, vb. çekiciliklerinden turistlerin genel fiyat değerlendirmelerine kadar birçok unsur etkili olabilmektedir. Tüm bu unsurların yanı sıra 
destinasyonlarda turistlerin elde edecekleri dinlenme, snobizm, kendini gerçekleştirme, vb. faydaların yanı sıra destinasyonlarda yaşayacakları unutulmaz deneyimleri de son derece önemlidir. Turistlerin destinasyonda yaşayacakları olumlu deneyimler destinasyonun gelişmesine, tanınırlığına, turistlerde tekrar ziyaret davranışının oluşturulmasına olumlu katkı sağlayacaktır (Çelik ve Gökçe, 2015: 30). Yoğun rekabetin yaşandığı turizm işletmelerinde ve destinasyonlarında turist sadakati oluşturmanın birçok farklı yöntemi, aracı ve stratejisi (toplam maliyet liderliği, farklılaşma ve odaklanma) bulunmaktadır (Bahar ve Kozak, 2005: 152). Ancak benzersiz ve olumlu deneyimler temelinde oluşturulacak sadakat turistlerin duygusal ve rasyonel tatminlerinin ve ilgili destinasyonu tekrar ziyaret niyetlerinin sağlanmasına yardımcı olacaktır. $\mathrm{Bu}$ kapsamda destinasyon yönetim örgütlerinin, planlamacılarının ve pazarlamacılarının turistlerin deneyimlerini doğru değerlendirmeleri, turistlerle empati kurabilmeleri ve fayda odaklı üretimden ve sunumdan deneyim odaklı süreç yönetimine yönelmeleri gerekmektedir (Altunışık ve diğerleri, 2011: 185).

Deneyim kavramı 1980'li yıllarla birlikte tüketici davranışları literatüründe sıklıkla kullanılmaya başlanmıştır. Deneyim kavramı; "tüketiciler açısından kendiliğinden oluşmayan aksine kimi tetikleyiciler sayesinde oluşan özel olaylar" (Schmitt 1999); "tüketiciler için önem arz eden duygusal, fiziksel, entelektüel ve ruhsal unsurların karışımı” (Mossberg, 2007) ve "tüketiciler açısından tüketim esnasında oluşan eğlenceli, bağlayıcı ve unutulmaz karşılaşmalar" (Oh ve diğerleri, 2007) olarak tanımlanmaktadır. Deneyim yaklaşımında tüketiciler sadece fayda beklentisi içerisinde olan rasyonel karar vericiler olmaktan öteye tüketicilerin düşünen, hisseden ve duyguları olan varlıklar olarak değerlendirilmesi gerektiği savunulmaktadır (Addis ve Holbrook, 2001: 50). Çünkü tüketiciler her ne kadar rasyonel kararlar alsalar da bu kararların temelinde duyguları (hayal gücü, hisler ve eğlence) yer almaktadır. Bir çağdaş pazarlama yaklaşımı olarak deneyimsel pazarlamada da tüketicilerin duygularına ve deneyimlerine odaklanılmaktadır. Deneyimsel pazarlamada diğer geleneksel pazarlama yaklaşımlarından farklı olarak fayda temelli (Schmitt, 1999: 11-12) bir anlayıştan duygu temelli bir anlayışa geçiş, turistlere gittikleri destinasyonlarda farklı ve unutulmaz deneyimler yaşatmak, bu şekilde destinasyonların tanıtımını yapmak ve potansiyel turistleri etkilemek amaçlanmaktadır (Çelik ve Gökçe, 2015: 33). Deneyimsel pazarlama dört temel özellik üzerine kurgulanmıştır. Deneyimsel pazarlamanın özellikleri; tüketicilerin fonksiyonel/fayda beklentisi yerine tüketicilerin hisleri, duyguları ve bilinçleri odaklı olması “tüketici deneyimi”, tüketicilerin kendilerine yönelik birkaç ürünü tek tek değil bir bütün olarak değerlendirmesi "bütünsel bir deneyim olarak tüketim" (turistlerin tatillerindeki 
yararlandıkları konaklama işletmelerini, seyahat işletmelerini, turistik çekicilikleri, vb. tek tek değerlendirmeleri yerine tüm ürünleri ve hizmetleri destinasyon olarak değerlendirmeleri gibi), tüketicilerin satın alma kararlarının işletmeler tarafından rasyonelliğinin yanı sıra duygu yönüyle de değerlendirilmesi “duygusal düşünen tüketiciler” ve işletmelerin tüketicilerin metodolojik ideoloji ile sınırlamayıp eklektik değerlendirmesi “eklektiklik" olarak özetlenebilir (Schmitt, 1999: 11-12). Deneyimsel pazarlamada tüketicilerin birbirlerinden farklı; duyusal (sense-beş duyuya yönelik duyusal deneyim), duygusal (feel-ruh haline ve hislere yönelik duygusal deneyim), bilişsel (think-bilişsel ve yaratıcılığa yönelik entelektüel deneyim), fiziksel (act-fiziksel davranışlara ve yaşam tarzına yönelik davranışsal deneyim) ve sosyal (relate-kültürel ve doğrulayıcı gruplara yönelik ilişkisel deneyim) deneyim olmak üzere beş temel deneyim boyutunu yaşayabilecekleri ileri sürülmektedir (Nagasawa, 2008: $315)$.

Deneyimsel pazarlama turistik işletmelerin ve destinasyonların marka değerinin arttırılmasında, rakiplerden farklılaşmalarında, inovasyon çalışmalarında, imajın geliştirilmesinde ve turist sadakatinin sağlanmasında önemli bir yaklaşım olarak öne çıkmaktadır. Deneyimsel pazarlama üzerine kurgulandığı özellikler kapsamında turistlerin destinasyon ve turistik ürün satın alma karar süreçlerinin öncesinden başlayarak destinasyonun ve ürünün deneyimlenmesi ve deneyim sonrası değerlendirmelerini kapsayan bütünsel bir süreci ifade etmektedir. $\mathrm{Bu}$ sürecin doğru bir şekilde anlaşılabilmesi ve yönetilebilmesi için turistlerin deneyimleri ile ilgili ipuçlarının bulunması gerekmektedir. Turistlerde deneyim yaratan ipuçları mantıksal yorumlara dayanan "rasyonel deneyim"; hislere ve duyulara yönelik yorumlara dayanan "duygusal deneyim" boyutlarında sinıflandırılmaktadır (Cavlak, 2007: 37). Rasyonel deneyim boyutu turistlerin karar verme süreçlerinde katlanacakları maliyetleri (zaman, para, alternatif maliyet, vb.) ve elde edecekleri faydayı (dinlenme, kendini gerçekleştirme, vb.) değerlendirmelerinden oluşur. Turistler alternatif destinasyonlar arasında seçim yaparken rasyonel davranışlar sergilemektedirler ve en uygun fiyata en iyi hizmeti alacaklarını düşündükleri destinasyonu tercih etmektedirler (Sirakaya ve Woodside, 2005: 820). Turistlerde rasyonel deneyim boyutu; seyahat öncesi hazırlık deneyiminden, destinasyonda yaşanan deneyiminden ve öğrenme deneyiminden oluşmaktadır (Cavlak, 2007: 41-55). Duygusal deneyim boyutunda ise turistlere destinasyonlarda ve tatilleri esnasında keyifli deneyimler yaşamalarını sağlamak için duygusal varlıklar olarak değerlendirilmeleri söz konusudur (Williams, 2006: 485). Duygusal deneyimde temel kriter turistlerin destinasyonlarda kendilerine sundukları ürünlerden ve 
hizmetlerden elde ettikleri deneyimlerdir. Turistler yaşadıkları deneyimler doğrultusunda destinasyonları konumlandırmaktadırlar (Oh ve diğerleri, 2007: 119). Duygusal deneyim boyutları; turistlerin turistik etkinliklere katılım düzeyi (aktif-kayak yapan turist, vb. ve pasiftiyatro oyunu izleyen turist, vb. olma durumları); turistlerin zihinsel ve fiziksel performansları çerçevesinde (zihinsel/özümseme-televizyonda film izleme, vb. ve fiziksel/sarmalama-sinema salonunda film izleme, vb.) eğlence (pasif-özümseme), öğrenme (aktif-özümseme), estetik (pasif-sarmalama) ve kaçış (aktif-sarmalama) deneyimlerinden oluşmaktadır (Pine ve Gilmore, 1998: 102).

Bu kapsamda yapılan bu çalışmanın temel amacını Kapadokya destinasyonunu ziyaret eden yerli turistlerin algıladıkları rasyonel ve duygusal deneyim boyutlarının belirlenmesi oluşturmaktadır. Yapılan bu araştırmanın ilgili destinasyona, literatüre ve sonraki çalışmalara katkı sağlayacağı düşünülmektedir. Çünkü konu kapsamında Kapadokya destinasyonunda daha önce yürütülmüş bir çalışmaya ulaşılamamıştır. $\mathrm{Bu}$ anlamada çalışmanın ilgili destinasyona teorik ve uygulama temelli sonuçları itibariyle önemli katkılar sağlayacağı öngörülmektedir.

\section{ILLIILI ARAŞTIRMALAR}

Pine ve Gilmore (1998) "Deneyim Ekonomisi” çalışmalarında bir deneyimin birden fazla boyutta tüketicileri çekebileceğini öne sürmüşlerdir. Yazarlar ilgili deneyim boyutlarını; etkinliklere tüketici katılımı (aktif-pasif), tüketicilerin zihinsel ve fiziksel performansları (özümseme-sarmalama) ve tüketici deneyimi boyutları (estetik, kaçış, eğlence ve öğrenme) olarak sınıflandırmışlardır.

Meng (2006) Virginia destinasyonunda konaklayan 18 yaş ve üzeri 330 katılımcı ile yürüttüğü çalışmasında turizm deneyim kalitesi ölçeğini test etmiştir. Araştırma sonucunda; seyahat öncesi hazırlık aşaması, destinasyonda yaşanan deneyimler ve öğrenme deneyimini rasyonel deneyim boyutları olarak belirlemiştir.

Oh ve diğerleri (2007) Amerika Midwest destinasyonunda yer alan konaklama işletmelerinden hizmet alan 245 katılımeı ile gerçekleştirdikleri çalışmalarında turist deneyimlerinde estetik boyutunun kaçış ve eğlence boyutu kadar belirleyici bir boyut olduğu sonucuna ulaşmışlardır.

Hosany ve Prayag (2013) İngiltere'nin Güney Doğu'sunda yer alan bir kasabada 520 katılımcı ile gerçekleştirdikleri çalışmalarında eğlence, sevgi, pozitif sürpriz ve memnuniyetsizlik deneyimlerini duygusal deneyim boyutları olarak belirlemişlerdir. 


\section{Ankara Hacı Bayram Veli Üniversitesi Turizm Fakültesi Dergisi \\ Ünal, 2020, Cilt: 23, Sayl: 2, 374-393}

Prayag ve diğerleri (2017) İtalya Sardinia destinasyonunu ziyaret eden 350 yerli turistin katılımı ile yürüttükleri çalışmalarında turistlerin destinasyonlarda algıladıkları duygusal deneyim unsurlarının (eğlence, sevgi ve pozitif sürpriz) algıladıkları destinasyon imajlarını olumlu etkilediği ve bu durumun algilanan destinasyon genel memnuniyetine ve tekrar ziyaret niyetine olumlu katkı sağladığı sonucuna ulaşmışlardır.

Cavlak (2017) Mart-Nisan-Mayıs 2016'da Çanakkale-Gelibolu Yarımadası Tarihi Milli Parkı'nı ziyaret eden 493 Türk ve Anzak katılımcı ile gerçekleştirdiği çalışmasında; rasyonel ve duygusal deneyim boyutlarını ve bu boyutlarla algılanan destinasyon imajı ilişkisini test etmiştir. Araştırma sonucunda rasyonel deneyim boyutları olarak seyahat öncesi hazırlık deneyimi, destinasyonda yaşanan deneyim ve öğrenme deneyimi boyutları; duygusal deneyim boyutları olarak ise eğlence ve kaçış deneyimi ve estetik deneyimi boyutları belirlenmiştir.

Çavuşoğlu ve Bilginer (2018) Bingöl ilinde 298 katılımcı ile yürüttükleri çalışmalarında deneyim boyutları ile tekrar ziyaret niyeti ilişkisini test etmişlerdir. Araştırma sonucunda deneyim boyutları ile tekrar ziyaret niyeti arasında anlamlı ve pozitif ilişkilerin varlığ 1 tespit edilmiştir.

Akkuş (2019) Ankara ilini ziyaret eden 509 yerli turistle gerçekleştirdiği çalışmasında destinasyon deneyim boyutlarını (sevinç, sevgi, pozitif sürpriz ve memnuniyetsizlik) ile destinasyon bileşenlerini (çekicilik-erişilebilirlik, fiyat ve olanak) test etmiştir. Araştırma sonucunda ilgili boyutlar arasında anlamlı ve pozitif ilişkilerin varlığı tespit edilmiştir.

Genel anlamda destinasyonları değerlendiren ve analiz eden bu çalışmaların yanı sıra destinasyon bileşenleri kapsamında konuyu ele alan güncel çalışmalar ve sonuçları ise aşağıda özetlenmiştir.

Hosany ve Witham (2010) Singapur-Hong Kong rotasında kruvaziyer deneyimi yaşayan 1859 katılımcı ile gerçekleştirdikleri çalışmalarında turistlerin duygusal deneyim boyutlarını test etmişlerdir ve eğlence, öğrenme, estetik ve kaçış deneyimini duygusal deneyim boyutları olarak belirlemişlerdir.

Mehmetoğlu ve Engen (2011) Güney Norveç’te düzenlenen Ice Müzik Festivali'ne katılan ve Maihaugen Müzesi’ni ziyaret eden 192 katılımcı ile gerçekleştirdikleri çalışmalarında estetik, eğlence, kaçış ve öğrenme deneyim boyutlarının memnuniyet düzeyi ile ilişkisini test etmişlerdir. Müzik festivaline katılan ziyaretçilerin kaçış deneyimlerinin memnuniyetleri üzerinde; müze ziyaretine katılan ziyaretçilerin ise öğrenme deneyimlerinin memnuniyetleri üzerinde daha fazla etkiye sahip olduğunu belirlemişlerdir. 
Wang ve diğerleri (2013) Macau'da bulunan kumarhane otellerini ziyaret eden 473 katılımc1 ile gerçekleştirdikleri çalışmalarında; turistlerin demografik özelliklerine göre deneyim boyutlarının farklılaşıp farklılaşmadığını test etmişlerdir. Araştırmanın sonuçlarına göre cinsiyet değişkeni ile eğlence deneyiminin; yaşam yerleri ile eğlence ve öğrenme deneyimlerinin; meslek değişkeni ile eğlence ve estetik deneyimlerinin farklılaştığı tespit edilmiştir. Ayrıca turistlerin gelir ve eğitim düzeyleri ile yaşadıkları deneyim boyutları arasında anlamlı bir bağlılık tespit edilememiştir.

Yetiş Ardıç (2015) termal otel işletmelerinde deneyimsel pazarlama yaklaşımı konusunda yürüttüğü nitel çalışmasında duyusul, duygusal, bilişsel, davranışsal ve ilişkisel deneyimi deneyimsel pazarlama boyutları olarak öne çıkarmıştır.

Deligöz ve Ünal (2016) iki farklı kahve zincirinden hizmet alan 300 katılımcı ile yürüttükleri çalışmalarının sonucunda marka deneyimi boyutları olarak duyusul, duygusal, bilişsel, davranışsal ve ilişkisel deneyimi test etmişlerdir.

Taşkıran ve Kızılırmak (2019) İstanbul Panorama 1453 Tarih Müzesi’ni 360 sanal tur ile deneyimleyen 6 kişilik katılımcı grubu ile yürüttükleri çalışmalarında sanal tur deneyiminin gerçek ziyaret deneyimi hissini vermediği ve gerçek ziyareti de teşvik etmediği sonucuna ulaşmışlardır.

\section{YÖNTEM}

\subsection{Araştırma Amacı ve Araştırma Alanının Seçimi}

Yapılan bu çalışmanın temel amacını Kapadokya destinasyonunu ziyaret eden yerli turistlerin algıladıkları rasyonel ve duygusal deneyim boyutlarının belirlenmesi oluşturmaktadır. İlgili destinasyonun araştırma alanı olarak seçilmesinde; M.Ö. 3000 yılına dayanan tarihi geçmişini ve kültürel değerlerini, dünyaca ünlü peribacalarını ve diğer doğal güzelliklerini, şarapçılıkbağcılık, çömlekçilik, atçılık (Pers dilinde bölge güzel atlar ülkesi-Katpatika olarak da anılır), halıcılık, oniks taş işlemeciliği ve diğer el sanatlarını, zengin gastronomik kültürünü ve sıcak hava balonu turlarını turistlere deneyimleme firsatı sunması, özellikle Uzak Doğulu yapımcılar ve belgeselciler tarafindan (1969'dan günümüze 32 ülkeden 193 yapıma ev sahipliği yapmıştır) sıklıkla dekor olarak tercih edilmesi, destinasyonun 6 Aralık 1985 tarihinde UNESCO Dünya Mirası Listesi'ne dâhil edilmesi ve Nuri Bilge CEYLAN'ın destinasyonda çektiği Kış Uykusu filminin 67. Cannes Film Festivali'nde Altın Palmiye ödülünü kazanması birlikte ulusal ve uluslararası tanınırlığının ve bilinirliğinin artması etkili olmuştur. 


\subsection{Araştırmanın Veri Toplama Aracı}

Araştırmanın amacını ve kapsamını oluşturan destinasyonlarda turistlerin algıladıkları rasyonel ve duygusal deneyim boyutlarını belirlemeye ve ölçmeye yönelik çalışmalar yerli ve yabanc1 literatürde mevcuttur (Pine ve Gilmore, 1998; Meng, 2006; Oh ve diğerleri, 2007; Nagasawa, 2008; Hosany ve Witham, 2010; Mehmetoğlu ve Engen, 2011; Hosany ve Prayag, 2013; Wang ve diğerleri, 2013; Yetiş Ardıç, 2015; Kara, 2015; Kara ve Kimzan, 2016; Deligöz ve Ünal, 2016; Prayag ve diğerleri, 2017; Cavlak, 2017; Demirtaş, 2017; Cavlak ve Cop, 2018; Çavuşoğlu ve Bilginer, 2018; Akkuş, 2019; Taşkıran ve Kızılırmak, 2019). Araştırma anketinin ve önermelerinin oluşturulmasında da ilgili çalışmalardan Cavlak (2017) yararlanılmıştır. İki bölümden oluşan araştırma anket formunun ilk bölümü 12 demografik sorudan ve bu sorulara yönelik cevaplandırıcının seçebileceği ifadelerden; anket formunun ikinci bölümü ise araştırma boyutlarına ilişkin 21'i rasyonel deneyim ve 10'nu duygusal deneyim olmak üzere toplam 31 likert tipi ifadeden (kesinlikle katılıyorum-kesinlikle katılmıyorum aralığından seçmeli) oluşmaktadır. Yerli turistlerin cinsiyetleri, medeni durumları, yaş aralıkları, eğitim düzeyleri, meslekleri, aylık gelir düzeyleri, destinasyonu ziyaret nedenleri, destinasyonla ilgili bilgi kaynakları, tatillerini birlikte geçirdikleri kişi veya kişiler, destinasyona geliş şekilleri, tatilleri ile ilgili genel memnuniyet düzeyleri ve destinasyonu tekrar ziyaret niyetleri araştırma anketinin demografik değişkenlerini oluşturmaktadır.

\subsection{Araştırmanın Evreni ve Örneklemi}

Araştırmanın veri toplama sürecinde (1 Mayıs-30 Kasım 2018) ilgili destinasyonu tam olarak kaç yerli turistin ziyaret ettiği ile ilgili bir istatistiğe ulaşılamamıştır. $\mathrm{Bu}$ nedenle cevaplayıcıların yönettiği toplam 260 anket formu destinasyonu ziyaret etmekte olan yerli turistlere yüz yüze iletişim sağlanarak uygulanmıştır. Anket uygulanan yerli turistlerin belirlenmesinde zaman ve maliyet avantaj1, erişim kolaylığı ve eldeki mevcut veya gönüllü bireylere uygulanması avantajları nedeniyle olasılığa dayalı olmayan örnekleme yöntemlerinden kolayda örnekleme tekniğinden yararlanılmıştır (Erkuş, 2011: 106). Geri dönüş sağlanan anketlerden 20 tanesi cevap kodlamalarının \%50'sinden fazlasının boş bırakılmasından veya aynı cevap seçeneğinin birden fazla kez doldurulmasından dolayı değerlendirme dışında bırakılmıştır. Araştırmanın değerlendirme kısmına 240 anket dâhil edilmiştir ve anketlerin geri dönüş oranı \%92 olarak gerçekleşmiştir. 


\subsection{Araştırma Verilerinin Analizi}

Araştırma sonucunda anket formlarından elde edilen veriler SPSS istatistikî veri programında analize tabi tutulmuştur. Araştırma anketinden elde edilen yerli turistlerin demografik değişkenlerine ilişkin veriler yüzde ve frekans değerleriyle analiz edilmiştir. Ölçekteki likert tipi ifadelerin güvenirliği Cronbach's Alpha katsayısından yararlanılarak analiz edilmiştir. Güvenirlik analizinin yapılabilmesi için çalışmada en az 20 ifade ve 50 denek olması gerekmektedir (Ural ve Kılıç, 2005: 258). Bu çalışmaya dâhil edilen ifade ve denek sayıları ilgili testi yapmak için yeterlidir. Alpha değeri faktör altındaki soruların toplamdaki güvenirlik seviyesini göstermektedir. Bu değerin 0,70 ve üstü olduğu durumlarda araştırma ölçeği güvenilir olarak kabul edilmektedir (Hair ve diğerleri, 1998). Bu kapsamda yapılan güvenirlik analizi sonucunda araştırmada kullanılan yerli turistlerin "Destinasyon Rasyonel ve Duygusal Deneyimlerini Değerlendirmelerine” ilişkin ölçeğin Alpha katsayısı ,944 olarak bulunmuştur. Elde edilen katsayı oranları ölçeğin güvenilir olduğuna işaret etmektedir (Ural ve Kılıç, 2005: 258). Ölçekle ilgili diğer testlere geçilmeden önce ölçeğin normallik testi yapılmıştır. Normallik testinde verilerin Shapiro-Wilks değerlerinin anlamlılık düzeyinin $\mathrm{p}>0,05$ olduğu tespit edilmiştir. Bu sonuç ölçeğin parametrik testler ( $t$ test, ANOVA, vb.) için uygun olduğunu göstermektedir (Tabachnick ve Fidell, 2013). Güvenirlik ve normallik analizlerinden sonra yerli turistlerin algıladıkları "Destinasyon Rasyonel ve Duygusal Deneyim Boyutlarını" değerlendirmelerine ilişkin ölçeğin yapı geçerliğini test etmek amacıyla açıklayıcı (keşfedici) faktör analizi yapılmıştır.

\section{BULGULAR}

Araştırma katılımcılarının demografik özelliklerine ilişkin yapılan frekans analizi sonuçlarına göre (Tablo 1) katılımcıların çoğunluğunun; erkek (\%55), evli (\%66,6), 25-60 yaş aralığında (\%43), lisans düzeyinde eğitime sahip (\%42,5), özel sektör çalışanı $(\% 32,5), 5001$ TL ve üzerinde aylık gelire sahip $(\% 38,7)$, destinasyonu fiyat açısından uygun bulduğu için tercih eden $(\% 35,8)$, destinasyon hakkında sosyal medya ve internet temelli araçlarından bilgi edinen $(\% 35,4)$, destinasyonu eşi ve çocuklarıyla $(\% 31,2)$ ve paket tur satın alarak $(\% 56,3)$ ziyaret eden yerli turistlerden oluştukları belirlenmiştir. Ayrıca katılımcıların destinasyondan genel olarak memnun kaldıkları $(\% 81,2)$ ve destinasyonu tekrar ziyaret niyetinde oldukları $(\% 73,7)$ da tespit edilmiştir. 
Tablo 1. Katılımcıların demografik dağılımları $(n=240)$

\begin{tabular}{|c|c|c|c|}
\hline Demografik Özellikler & & Sayı (n) & Yüzde (\%) \\
\hline \multirow{2}{*}{ Cinsiyet } & Kadın & 108 & 45,0 \\
\hline & Erkek & 132 & 55,0 \\
\hline \multirow{2}{*}{ Medeni Durum } & Evli & 160 & 66,6 \\
\hline & Bekâr & 80 & 33,4 \\
\hline \multirow{3}{*}{ Yaş } & 15-24 Yaş Aralığ1 & 39 & 16,2 \\
\hline & 25-60 Yaş Aralığ1 & 103 & 43,0 \\
\hline & 61 Yaş ve Üzeri & 98 & 40,8 \\
\hline \multirow{5}{*}{ Ĕ̆itim Düzeyi } & İlköğretim & 11 & 4,6 \\
\hline & Lise & 40 & 16,7 \\
\hline & Önlisans & 55 & 22,9 \\
\hline & Lisans & 102 & 42,5 \\
\hline & Lisansüstü & 32 & 13,3 \\
\hline \multirow{5}{*}{ Meslek } & Öğrenci & 24 & 10,0 \\
\hline & Kendi İşinde Çalışan & 66 & 27,5 \\
\hline & Özel Sektör Çalışanı & 78 & 32,5 \\
\hline & Kamu Çalışanı & 32 & 13,3 \\
\hline & Emekli & 40 & 16,7 \\
\hline \multirow{3}{*}{ Aylık Gelir } & $0-2500 \mathrm{TL}$ & 69 & 28,8 \\
\hline & $2501 \mathrm{TL}-5000 \mathrm{TL}$ & 78 & 32,5 \\
\hline & 5001 TL ve Üzeri & 93 & 38,7 \\
\hline \multirow{4}{*}{ Destinasyonu Tercih Nedeni } & Daha Önceki Ziyaretim & 56 & 23,3 \\
\hline & Tavsiye Üzerine & 55 & 22,9 \\
\hline & Fiyat Açısından Uygun & 86 & 35,9 \\
\hline & Yaşadığım Yere Yakın & 43 & 17,9 \\
\hline \multirow{4}{*}{$\begin{array}{l}\text { Destinasyonla } \\
\text { Kaynakları }\end{array}$} & Daha Önceki Ziyaretim & 56 & 23,3 \\
\hline & Seyahat Acentası & 65 & 27,1 \\
\hline & Sosyal Medya-İnternet & 85 & 35,4 \\
\hline & Arkadaş Çevresi & 34 & 14,2 \\
\hline \multirow{6}{*}{$\begin{array}{l}\text { Tatilini Birlikte Geçirdiğin } \\
\text { Kişiler }\end{array}$} & Yalnızım & 22 & 9,2 \\
\hline & Eşimle & 58 & 24,1 \\
\hline & Eşim ve Çocuklarımla & 75 & 31,2 \\
\hline & Ailemle (Ebeveynler) & 25 & 10,4 \\
\hline & Kız-Erkek Arkadaşımla & 28 & 11,6 \\
\hline & Arkadaş Grubumla & 32 & 13,5 \\
\hline \multirow{2}{*}{ Destinasyona Geliş Şekli } & Münferit & 105 & 43,7 \\
\hline & Paket Tur & 135 & 56,3 \\
\hline \multirow{2}{*}{ Genel Memnuniyet Düzeyi } & Evet & 177 & 81,2 \\
\hline & Hayır & 63 & 18,8 \\
\hline \multirow{2}{*}{ Tekrar Ziyaret Niyeti } & Evet & 195 & 73,7 \\
\hline & Hayır & 45 & 26,3 \\
\hline & Toplam & 240 & 100 \\
\hline
\end{tabular}

Yerli turistlerin rasyonel deneyim önermelerine ilişkin değerlendirmelerine yönelik yapılan analiz (Descriptive) sonuçlarına göre (Tablo 2); destinasyonda emniyet ve güvenlik yeterlidir $(\tilde{\mathrm{X}}=4,12)$, destinasyonda yönlendirici bilgiler yeterlidir $(\tilde{\mathrm{x}}=4,06)$, destinasyonda yerel halk ile iyi iletişim kurdum ( $(\tilde{\mathrm{x}}=4,03)$, destinasyonda turistik çalışanlarla iyi iletişim kurdum $(\tilde{\mathrm{x}}=4,02)$, destinasyonda yüksek kalite hizmet aldım $(\widetilde{x}=4,01)$, destinasyonda öğrendiklerim beni daha fazla öğrenmeye teşvik etti $(\widetilde{\mathrm{X}}=4,01)$ ve destinasyonda genel olarak çok şey öğrendim $(\tilde{\mathrm{x}}=4,00)$ 
önermelerini değerlendirmeleri yüksek düzeyde gerçekleşmiştir. Yerli turistlerin rasyonel deneyim önermelerinden seyahatin fiyatını uygun buldum $(\tilde{\mathbb{x}}=2,98)$ ve destinasyonda turistik fiyatlar genel olarak uygundu $(\tilde{\mathrm{x}}=2,94)$ önermelerini değerlendirmeleri ise düşük düzeyde kalmıştır. Yerli turistlerin diğer rasyonel deneyim önermelerini değerlendirme düzeyleri ise orta ve birbirine yakın düzeyde $(\tilde{\mathrm{x}}=3,37-3,88)$ gerçekleşmiştir.

Tablo 2. Katılımcıların rasyonel deneyim değerlendirmeleri $(n=240)$

\begin{tabular}{|l|c|c|}
\hline \multicolumn{1}{|c|}{ Araştırma Önermeleri (Rasyonel Deneyim) } & Ort. $(\mathbb{\mathbf { X }})$ & Std. Sapma \\
\hline Seyahati planlamak için çok zaman harcadım. & 3,88 & 1,03 \\
\hline Seyahati planlarken bilgilere ulaşmam kolay oldu. & 3,87 & 1,08 \\
\hline Seyahati planlarken destinasyonla ilgili çok bilgi buldum. & 3,55 & 1,13 \\
\hline Seyahati planlarken uzmanlardan yüksek kalitede hizmet aldım. & 3,76 & 1,01 \\
\hline Seyahat hazırlıkları esnasında hiçbir problemle karşılaşmadım. & 3,45 & 1,10 \\
\hline Seyahatin fiyatını uygun buldum. & 2,98 & 1,23 \\
\hline Seyahatim esnasında destinasyonda hava çok güzeldi. & 3,37 & 1,22 \\
\hline Destinasyon eşsiz turizm kaynaklarına sahiptir. & 3,54 & 1,26 \\
\hline Destinasyon konaklama yerleri kalitelidir. & 3,39 & 1,20 \\
\hline Destinasyon yiyecek içecek yerleri kalitelidir. & 3,49 & 1,09 \\
\hline Destinasyonda çok çeşitli aktiviteler yapılabilmektedir. & 3,94 & 1,36 \\
\hline Destinasyonda seçim yapılabilecek kadar aktivite bulunmaktadır. & 3,37 & 1,32 \\
\hline Destinasyonda turistik fiyatlar genel olarak uygundu. & 2,94 & 1,06 \\
\hline Destinasyonda yüksek kalitede hizmet aldım. & $\mathbf{4 , 0 1}$ & 1,02 \\
\hline Destinasyon çevresi genel olarak temizdi. & 3,63 & 1,29 \\
\hline Destinasyonda yerel halk ile iyi iletişim kurdum. & $\mathbf{4 , 0 3}$ &, 99 \\
\hline Destinasyonda yönlendirici bilgiler yeterlidir. & $\mathbf{4 , 0 6}$ &, 97 \\
\hline Destinasyonda emniyet ve güvenlik yeterlidir. & $\mathbf{4 , 1 2}$ & 1,01 \\
\hline Destinasyonda turistik çalışanlarla iyi iletişim kurdum. & $\mathbf{4 , 0 2}$ & 1,04 \\
\hline Destinasyonda genel olarak çok şey öğrendim. & $\mathbf{4 , 0 0}$ & 1,08 \\
\hline Destinasyonda öğrendiklerim beni daha fazla öğrenmeye teşvik etti. & $\mathbf{4 , 0 1}$ & 1,12 \\
\hline
\end{tabular}

Yerli turistlerin duygusal deneyim önermelerine ilişkin değerlendirmelerine yönelik yapılan analiz (Descriptive) sonuçlarına göre (Tablo 3); destinasyon aktivitelerini takip ederek çok eğlendim $(\tilde{\mathrm{x}}=4,06)$, destinasyonda kendimi farklı bir karakter olarak hissettim $(\tilde{\mathrm{x}}=4,05)$ ve destinasyon çok etkileyici bir yerdi $(\widetilde{X}=4,01)$ önermelerini değerlendirmeleri yüksek düzeyde gerçekleşmiştir. Yerli turistlerin diğer duygusal deneyim önermelerini değerlendirme düzeyleri ise orta ve birbirine yakın düzeyde $(\tilde{\mathrm{x}}=3,47-3,65)$ gerçekleşmiştir.

Tablo 3. Katılımcıların duygusal deneyim değerlendirmeleri $(n=240)$

\begin{tabular}{|l|c|c|}
\hline \multicolumn{1}{|c|}{ Araştırma Önermeleri (Duygusal Deneyim) } & Ort. $\left(\mathbb{\mathbf { x }}_{\text {) }}\right.$ & Std. Sapma \\
\hline Destinasyonda gerçek bir ahenk hissettim. & 3,51 & 1,13 \\
\hline Destinasyonda olmak çok zevkliydi. & 3,62 & 1,06 \\
\hline Destinasyon çok etkileyici bir yerdi. & $\mathbf{4 , 0 1}$ & 1,04 \\
\hline Destinasyonun yerleşimi duyularıma haz verdi. & 3,91 & 1,03 \\
\hline Destinasyonda çok eğlendim. & 3,65 & 1,17 \\
\hline Destinasyon aktivitelerini takip ederek hoş vakit geçirdim. & 3,61 & 1,21 \\
\hline Destinasyon aktivitelerini takip ederek çok eğlendim. & $\mathbf{4 , 0 6}$ & 1,02 \\
\hline Destinasyonda kendimi farklı bir karakter olarak hissettim. & $\mathbf{4 , 0 5}$ & 1,10 \\
\hline
\end{tabular}




\begin{tabular}{|l|c|c|}
\hline $\begin{array}{l}\text { Destinasyonda kendimi farklı bir zamanda ve mekânda yaşıormuş } \\
\text { gibi hissettim. }\end{array}$ & 3,63 & 1,14 \\
\hline $\begin{array}{l}\text { Destinasyonda kendimi gerçek yaşamdan tamamen uzaklaşmış } \\
\text { hissettim. }\end{array}$ & 3,47 & 1,18 \\
\hline
\end{tabular}

Çalışmada yararlanılan rasyonel deneyim ölçeğine uygulanan açıklayıcı faktör analizi sonucunda (Tablo 4); KMO değeri ,895 olarak ( $\mathrm{p}=0,000$ anlamlılık düzeyinde) belirlenmiştir. $\mathrm{Bu}$ değer literatürde kabul görmüş değer aralıkları çerçevesinde mükemmel olarak değerlendirilmektedir (Durmuş ve diğerleri, 2010: 79). Ayrıca Barlett's Test of SphericityKüresellik Testi sonucu 2567,648 olarak tespit edilmiştir. Bu oranın düzeyi de örnekleme büyüklüğünün faktör analizi için yeterli ve uygun olduğunu göstermektedir. Açıklayıcı faktör analizinde oluşturulan matrislerin her bir elemanı her bir değişkenle her bir faktör arasındaki korelâsyonu gösteren faktör ağırlıklarıdır. Rotasyona tabi tutulmamış matrisin yorumlanması oldukça güçtür ve matrisin varimax rotasyonuna tabi tutulması gerekmektedir (İlban, 2008: 133). Çalışmada hem faktör yükleri açısından 0,30'un altında olan hem de eşkökenlilik (communalities) değerleri 0,50'nin altında olan önermeler değerlendirme dışı bırakılarak açıklayıcı faktör analizinin geçerliliğinin arttırılması amaçlanmıştır (Altunışık ve diğerleri, 2007: 225-227). Yapılan bu iki işlem sonucunda ölçekte yer alan 21 önermeden 4'ünün (seyahat hazırlıkları esnasında hiçbir problemle karşılaşmadım, seyahatin fiyatını uygun buldum, destinasyonda çok çeşitli aktiviteler yapılabilmektedir ve destinasyonda seçim yapılabilecek kadar aktivite bulunmaktadır) ölçekten çıkarılmasına karar verilmiştir. Kalan 17 önerme ile ikinci kez uygulanan açıklayıcı faktör analizi sonucunda bu önermelerin 3 boyut altında toplandığı belirlenmiştir ve ilgili boyutların "Destinasyon Rasyonel Deneyim Değerlendirme Ölçeği” boyutları olarak Destinasyonda Yaşanan Deyenim (DYD), Seyahat Öncesi Hazırlık Deneyimi (SÖHD) ve Öğrenme Deneyimi (ÖD) şeklinde adlandırılmalarına karar verilmiştir.

Destinasyonda Yaşanan Deneyim (DYD) boyutu; seyahatim esnasında destinasyonda hava çok güzeldi, destinasyon eşsiz turizm kaynaklarına sahiptir, destinasyon konaklama yerleri kalitelidir, destinasyonda yiyecek içecek yerleri kalitelidir, destinasyonda turistik fiyatlar genel olarak uygundu, destinasyonda yüksek kalitede hizmet aldım, destinasyon çevresi genel olarak temizdi, destinasyonda yerel halk ile iyi iletişim kurdum, destinasyonda emniyet ve güvenlik yeterlidir ve destinasyonda turistik çalışanlarla iyi iletişim kurdum önermelerinden oluşmaktadır. Boyut toplam varyansın \%38,414'ünü açıklamaktadır ve boyutun güvenirlik katsayısı ,922 olarak gerçekleşmiştir. 
Seyahat Öncesi Hazırlık Deneyimi (SÖHD) boyutu; seyahatimi planlarken destinasyonla ilgili bilgilere ulaşmam kolay oldu, seyahatimi planlarken destinasyondaki turistik uzmanlardan yüksek kalitede hizmet aldım, seyahatimi planlarken çok zaman harcadım ve seyahatimi planlarken destinasyonla ilgili çok bilgi buldum önermelerinden oluşmaktadır. Boyut toplam varyansın \%15,926'sını açıklamaktadır ve boyutun güvenirlik katsayısı ,750 olarak gerçekleşmiştir.

Öğrenme Deneyimi (ÖD) boyutu; destinasyonda yönlendirici bilgiler yeterlidir, destinasyonda genel olarak çok şey öğrendim ve destinasyonda öğrendiklerim beni daha fazla öğrenmeye teşvik etti önermelerinden oluşmaktadır. Boyut toplam varyansın \%10,494'ünü açıklamaktadır ve boyutun güvenirlik katsayısı ,778 olarak gerçekleşmiştir.

Tablo 4. Rasyonel deneyim ölçeği faktör analizi sonuçları $(n=240)$

\begin{tabular}{|c|c|c|c|}
\hline Rasyonel Deneyim Araștırma Önermeleri & DYD & SÖHD & ÖD \\
\hline Turistik çalışanlarla iyi iletişim kurdum. & ,806 & & \\
\hline Yerel halk ile iyi iletişim kurdum. & 804 & & \\
\hline Emniyet ve güvenlik yeterlidir. &, 800 & & \\
\hline Yüksek kalitede hizmet aldım. & ,782 & & \\
\hline Çevre genel olarak temizdi. & ,765 & & \\
\hline Seyahatim esnasında hava çok güzeldi. &, 712 & & \\
\hline Eşsiz turizm kaynaklarına sahiptir. & ,698 & & \\
\hline Konaklama yerleri kalitelidir. & 675 & & \\
\hline Yiyecek içecek yerleri kalitelidir. & ,656 & & \\
\hline Turistik fiyatlar genel olarak uygundu. & 621 & & \\
\hline Seyahati planlarken bilgilere ulaşmam kolay oldu. & & 727 & \\
\hline $\begin{array}{l}\text { Seyahati planlarken uzmanlardan yüksek kalitede hizmet } \\
\text { aldım. }\end{array}$ & & ,705 & \\
\hline Seyahati planlamak için çok zaman harcadım. & & 619 & \\
\hline Seyahati planlarken destinasyonla ilgili çok bilgi buldum. & & 607 & \\
\hline Destinasyonda yönlendirici bilgiler yeterlidir. & & & ,718 \\
\hline Destinasyonda genel olarak çok şey öğrendim. & & & ,645 \\
\hline $\begin{array}{l}\text { Destinasyonda öğrendiklerim beni daha fazla öğrenmeye } \\
\text { teşvik etti. }\end{array}$ & & &, 579 \\
\hline Cronbach Alpha & ,922 & ,750 & ,778 \\
\hline Açıklanan Varyans (\%) & $\mathbf{3 8 , 4 1 4}$ & 15,926 & 10,494 \\
\hline Toplam Açıklanan Var. (\%) & \multicolumn{3}{|c|}{64,834} \\
\hline KMO Değeri & \multicolumn{3}{|c|}{, 895} \\
\hline Barlett Küresel Test Değeri & \multicolumn{3}{|c|}{2567,648} \\
\hline Sig. p değeri-Olasılık Değeri & \multicolumn{3}{|c|}{, 000} \\
\hline
\end{tabular}

Duygusal deneyim önermelerine ilişikin uygulanan açıklayıcı faktör analzi sonucunda (Tablo 5) bu önermelerin 3 boyut altında toplandığı belirlenmiştir ve ilgili boyutların "Destinasyon Duygusal Deneyim Değerlendirme Ölçeği” boyutları olarak Eğlence Deneyimi (EĞD), Kaçış Deneyimi (KÇD) ve Estetik Deneyimi (ED) şeklinde adlandırılmalarına karar verilmiştir.

Eğlence Deneyimi (EĞD) boyutu; destinasyonda çok eğlendim, destinasyonun yerleşimi duyularıma haz verdi, destinasyon çok etkileyici bir yerdi, destinasyonda aktivitelerini takip 
ederek hoş vakit geçirdim ve destinasyon aktivitelerini takip ederek çok eğlendim önermelerinden oluşmaktadır. Boyut toplam varyansın \%51,511'ini açıklamaktadır ve boyutun güvenirlik katsayısı ,854 olarak gerçekleşmiştir.

Kaçış Deneyimi (KÇD) boyutu; destinasyonda kendimi farklı bir zamanda ve mekânda yaşıyormuş gibi hissettim, destinasyonda kendimi gerçek yaşamdan tamamen uzaklaşmış hissettim ve destinasyonda kendimi farklı bir karakter olarak hissettim önermelerinden oluşmaktadır. Boyut toplam varyansın \%12,281'ini açıklamaktadır ve boyutun güvenirlik katsayısı ,840 olarak gerçekleşmiştir.

Estetik Deneyimi (ED) boyutu; destinasyonda gerçek bir ahenk hissettim ve destinasyonda olmak çok zevkliydi önermelerinden oluşmaktadır. Boyut toplam varyansın \%8,150'sini açıklamaktadır ve boyutun güvenirlik katsayısı ,789 olarak gerçekleşmiştir.

Tablo 5. Duygusal deneyim ölçeği faktör analizi sonuçları $(n=240)$

\begin{tabular}{|c|c|c|c|}
\hline Duygusal Deneyim Araştırma Önermeleri & Ĕ̈D & KÇD & ED \\
\hline Destinasyonda çok eğlendim. &, 833 & & \\
\hline Destinasyonun yerleşimi duyularıma haz verdi. & ,744 & & \\
\hline Destinasyon çok etkileyici bir yerdi. & ,720 & & \\
\hline Destinasyon aktivitelerini takip ederek hoş vakit geçirdim. & ,687 & & \\
\hline Destinasyon aktivitelerini takip ederek çok eğlendim. & ,638 & & \\
\hline $\begin{array}{l}\text { Destinasyonda kendimi farklı bir zamanda ve } \text { mekânda } \\
\text { yaşıyormuş gibi hissettim. }\end{array}$ & & 890 & \\
\hline $\begin{array}{l}\text { Destinasyonda kendimi gerçek yaşamdan tamamen uzaklaşmış } \\
\text { hissettim. }\end{array}$ & & ,840 & \\
\hline Destinasyonda kendimi farklı bir karakter olarak hissettim. & & ,738 & \\
\hline Destinasyonda gerçek bir ahenk hissettim. & & & ,864 \\
\hline Destinasyonda olmak çok zevkliydi. & & & ,780 \\
\hline Cronbach Alpha & ,854 &, $\mathbf{8 4 0}$ & ,789 \\
\hline Açıklanan Varyans (\%) & $\mathbf{5 1 , 5 1 1}$ & 12,281 & 8,150 \\
\hline Toplam Açıklanan Var. (\%) & \multicolumn{3}{|c|}{71,942} \\
\hline KMO Değeri & \multicolumn{3}{|c|}{, $\mathbf{8 7 7}$} \\
\hline Barlett Küresel Test Değeri & \multicolumn{3}{|c|}{2225,763} \\
\hline Sig. p değeri-Olasılık Değeri & \multicolumn{3}{|c|}{, 000} \\
\hline
\end{tabular}

\section{SONUÇLAR VE ÖNERILLER}

Yapılan bu çalışmanın temel amacını Kapadokya destinasyonunu ziyaret eden yerli turistlerin algıladıkları rasyonel ve duygusal deneyim boyutlarının belirlenmesi oluşturmaktadır. $\mathrm{Bu}$ kapsamda katılımcıların demografik özelliklerini belirlemek amacıyla yapılan frekans analizi sonuçlarına göre yerli turistlerin çoğunluğunun erkek, evli, 25-60 yaş aralığında, lisans düzeyinde eğitime sahip, özel sektörde çalışan, 5001 TL ve üzerinde aylık gelire sahip katılımcılardan oluştukları belirlenmiştir. Katılımcıların çoğunluğu fiyat açısından uygun olduğu için destinasyonu tercih etmişlerdir. Katılımcıların yine büyük bir kısmı sosyal medyadan ve internetten edindikleri bilgiler çerçevesinde, eşleri ve çocuklarıyla ve paket tur 
satın alarak destinasyonu ziyaret etmişlerdir. Demografik değişkenlere ilişkin elde edilen sonuçlar destinasyonda daha önce yürütülmüş araştırma sonuçları ile özellikle de ziyaretçilerin yaş, eğitim, gelir, ziyaret nedeni, ziyaret şekli, vb. benzerlikler göstermektedir (Ahiler Kalkınma Ajans1, 2015). Yerli turistlerin \%81'i destinasyondan genel olarak memnun ayrıldıklarını ve destinasyonu tekrar ziyaret edeceklerini (\%74); \%19'u destinasyondan genel olarak memnun ayrılmadıklarını ve destinasyonu tekrar ziyaret etmeyeceklerini (\%26) ifade etmişlerdir. Elde edilen sonuç soyut ürünlerin ve hizmetlerin turistlere sunulduğu ve pazarlandığı turizm işletmelerinde ve turistik destinasyonlarda algılanan genel memnuniyet ve tekrar ziyaret niyeti davranışı ilişkisini göstermesi açısından son derece önemlidir ve ilgili literatür ile uyumludur (Qu ve Li, 1997; Duman ve Öztürk, 2005; Yoon ve Uysal, 2005; Ünlüönen ve Tokmak, 2009; Seçilmiş, 2012; Moutinho ve diğerleri, 2012; Beqiri ve diğerleri, 2014).

Yerli turistlerin rasyonel deneyim önermelerine ilişkin değerlendirmelerine yönelik yapılan analiz sonuçlarına göre; destinasyonda emniyet ve güvenlik yeterlidir, destinasyonda yönlendirici bilgiler yeterlidir, destinasyonda yerel halk ile iyi iletişim kurdum, destinasyonda turistik çalışanlarla iyi iletişim kurdum, destinasyonda yüksek kalite hizmet aldım, destinasyonda öğrendiklerim beni daha fazla öğrenmeye teşvik etti ve destinasyonda genel olarak çok şey öğrendim önermelerini değerlendirmeleri yüksek düzeyde gerçekleşmiştir. Yerli turistlerin rasyonel deneyim önermelerinden seyahatin fiyatını uygun buldum ve destinasyonda turistik fiyatlar genel olarak uygundu önermelerini değerlendirmeleri ise düşük düzeyde kalmıştır. İlgili sonuçlar kapsamında özellikle eğitim ve gelir seviyesi yüksek ve hem eşleri hem de çocukları ile seyahat eden ziyaretçilerin bulunduğu destinasyonlarda ziyaretçilerin öncelik verdiği destinasyon bileşenlerinin (fiyat, emniyet ve güvenlik, yönlendirici bilgiler, yerel halk ve turistik çalışanlarla iletişim, yüksek hizmet kalitesi, destinasyondaki öğretici unsurlar, vb.) ortaya konması açısından önemlidir. Ayrıca yerli turistlerin duygusal deneyim değerlendirmeleri açısından destinasyon aktivitelerini takip ederek çok eğlendim, destinasyonda kendimi farklı bir karakter olarak hissettim ve destinasyon çok etkileyici bir yerdi önermelerini değerlendirmeleri yüksek düzeyde gerçekleşmiştir. Destinasyon planlamacılarının, yöneticilerinin, örgütlerinin ve pazarlamacılarının bu sonuçlar çerçevesinde yürütecekleri çalışmalar son derece önem arz etmektedir.

Yapılan bu araştırmanın ilgili destinasyona, literatüre ve sonraki çalışmalara katkı sağlayacağı düşünülmektedir. Ancak araştırma maddi kaynaklar ve zaman sınırlığı dolayı daha geniş bir 


\section{Ankara Hacı Bayram Veli Üniversitesi Turizm Fakültesi Dergisi \\ Ünal, 2020, Cilt: 23, Sayl: 2, 374-393}

örneklem büyüklüğüne uygulanamamıştır. Bu sebeple gelecekteki çalışmalarda araştırmaya dâhil edilecek turist sayısının arttırılması ve milletleri açısından farklı turistlerinde örnekleme dâhil edilmesi araştırma sonuçlarının genellenmesi ve karşılaştırılması açısından olumlu katkı sağlayacaktır.

\section{KAYNAKÇA}

Addis, M. ve Holbrook, M. (2001). On the conceptual link between mass customisation and experiential consumption: an explosion of subjectivity. Journal of Consumer Behaviour, 1(1), $50-66$.

Ahiler Kalkınma Ajansı (2015). Kapadokya'da turizm yatırımı olanakları, [URL: http://investinnevsehir.com/assets/ilgilidosyalar/dokuman\%20merkezi/turizmyatirimolanaklari .pdf] (Erişim 04 Ocak 2020).

Akkuş, G. (2019). Destinasyon bileşenleri ile duygusal deneyimler arasındaki ilişki ve değişkenlerin davranışsal niyet üzerindeki etkisi. Elektronik Sosyal Bilimler Dergisi, 18(71), 1261-1277.

Altunışık, R., Çoşkun, R., Bayraktaroğlu, S., \& Yıldırım, E. (2007). Sosyal Bilimlerde Araştırma Yöntemleri-SPSS Uygulamalı. Sakarya: Sakarya Yayınc1lık.

Altunışık, R., Özdemir, Ş., \& Torlak, Ö. (2011). Pazarlamaya Giriş (Genişletilmiş 3. Baskı). Sakarya: Sakarya Yayınc1lık

Bahar, O., \& Kozak, M. (2005). Küreselleşme Sürecinde Uluslararası Turizm ve Rekabet Edebilirlik. Ankara: Detay Yayınc1lık.

Beqiri, M., Boriçi, A. ve Dergjini, A. (2014). An empirical study of service quality factors impacting tourist satisfaction and loyalty: Velipoja tourist destination. TMC Academic Journal, 8(2), 3648 .

Buhalis, D. (2000). Marketing the competitive destinaton of the future. Tourism Management, 21, 97116.

Cavlak, N. (2017). Müşteri deneyiminin destinasyon imajı üzerindeki etkileri: Türk ve Anzak turistler üzerine karşılaştırmalı bir araştırma (Yayınlanmamış Doktora Tezi), Abant İzzet Baysal Üniversitesi, Sosyal Bilimler Enstitüsü, İşletme Ana Bilim Dalı, Bolu.

Cavlak, N. ve Cop, R. (2018). Müşteri deneyiminin destinasyon imajı üzerindeki etkileri. Journal of Tourism and Gastronomy Studies, 6(4), 174-196.

Coltman, M. (1989). Tourism Marketing. New York: Van Nostrand Reinhold.

Crouch, G. (2000). Services in research destination marketing. International Journal of Hospitality \& Tourism Administration, 1(2), 65-86.

Çakıcı, C. ve Aksu, M. (2007). Çekim yeri seçiminde grup etkisi: yerel turistler üzerine bir araştırma. Anatolia: Turizm Araştırması Dergisi, 18(2), 183-194. 


\section{Ankara Hacı Bayram Veli Üniversitesi Turizm Fakültesi Dergisi \\ Ünal, 2020, Cilt: 23, Sayl: 2, 374-393}

Çavuşoğlu, S. ve Bilginer, G. F. (2018). Tüketici deneyimlerinin tekrar ziyaret etme niyetine etkisi: Gaziantep örneği. Türk Sosyal Bilimler Araştırmaları Dergisi, 3(1), 72-85.

Çelik, S. ve Gökçe F. (2015). Destinasyon pazarlamasında deneyimsel pazarlama uygulamalarının kullanımına ilişkin kavramsal bir çalışma. Elektronik Mesleki Gelişim ve Araştırma Dergisi, 3(1), 29-37.

Demirtaş, C. M. (2017). Limitlerin ötesini deneyimlemek: bir deneyimsel pazarlama çabası örneği olarak Nike Sub 2. Kırklareli Üniversitesi İktisadi ve İdari Bilimler Fakültesi Dergisi, 6(3), 4657.

Deligöz, K. ve Ünal, S. (2017). Deneyimsel pazarlama uygulamalarının marka tercihi üzerindeki etkisini belirlemeye yönelik bir araştırma (Kahve Dünyası ve Starbucks örneği). Atatürk Üniversitesi İktisadi ve İdari Bilimler Dergisi, 31(1), 135-156.

Duman, T. ve Öztürk, B. A. (2005). Yerli turistlerin Mersin Kızkalesi destinasyonu ve tekrar ziyaret niyetleri ile ilgili algılamaları üzerine bir araştırma. Anatolia: Turizm Araştırması Dergisi, $16(1), 9-23$.

Durmuş, B., Yurtkoru, S., \& Çinko, M. (2010). Sosyal Bilimlerde SPSS'le Veri Analizi. Ankara: Beta Yayınc1lik.

Erkuş, A. (2011). Davranış Bilimleri İçin Bilimsel Araştırma Süreci (Güncellenmiş Üçüncü Baskı). Ankara: Seçkin Yayıncılık.

Frisk, L. (1999), Separate worlds attitudes and values towards tourism development and co-operation among public organisations and private enterprises in Northern Sweden. Conference Proceedings of Forksarforum: Local Regional Utveckling, 16-17 November, Ostersund, Sweden.

Hair, J., Rolph, A., Tatham, R., \& Black, W. (1998). Multivariate Data Analysis (5th Edition). New Jersey: Prentice-Hall.

Hall, M. (2000). Tourism Planning: Policies, Processes and Relationships. London: Pearson Prentice Hall.

Hosany, S. ve Witham, M. (2010). Dimensions of cruisers' experiences, satisfaction, and intention to recommend. Journal of Travel Research, 49(3), 351-364.

Hosany, S. ve Prayag, G. (2013). Patterns of tourists' emotional responses, satisfaction and intention to recommend. Journal of Business Research, 66, 730-737.

İlban, O. M. (2008). Seyahat acenta yöneticilerinin destinasyon marka imajı algıları üzerine bir araştırma. Ege Akademik Bakış, 8(1), 121-152.

Kara, G. (2015). Marka deneyimi ve tekrar satın alma niyeti arasındaki ilişkide müşteri tatminin rolü (Yayınlanmamış yüksek lisans tezi), Eskişehir Osmangazi Üniversitesi, Eskişehir.

Kara, G. ve Kimzan, S. H. (2016). Marka deneyimi ve tekrar satın alma niyeti arasındaki ilişkide müşteri tatmininin rolü. Anadolu Üniversitesi Sosyal Bilimler Dergisi, 17(4), 73-90. 


\section{Ankara Hacı Bayram Veli Üniversitesi Turizm Fakültesi Dergisi \\ Ünal, 2020, Cilt: 23, Sayl: 2, 374-393}

Mehmetoğlu, M. ve Engen, M. (2011). Pine and Gilmore's concept of experience economy and its dimensions: an empiricial examination in tourism. Journal of Quality Assurance in Hospitality and Tourism, 12(4), 237-255.

Meng, F. (2006). An examination of destination competitiveness from the tourists' perspective: the relationship between quality of tourism experince and perceived destination competitiveness (Unpublished doctorate thesis), Virginia Tech University, Virginia.

Mossberg, L. (2007). A marketing approach to the tourist experience. Scandinavian Journal of Hospitality and Tourism, 7(1), 59-74.

Moutinho, L., Albayrak, T., \& Caber, M. (2012). How far does overall service quality of a destination affect customers' post-purchase behaviours?. International Journal of Tourism Research, 14(4), 307-322.

Nagasawa, S. (2008). Customer experince management: influencing on human kansei to management of technology. The TQM Journal, 20(4), 312-323.

Oh, H., Fiore, M., \& Jeoung, M. (2007). Measuring experience economy concepts: tourism applications. Journal of Travel Research, 46(2), 119-132.

Pine, J. ve Gilmore, J. (1998). Welcome to the experience economy. Harvard Business Review, 76(6), 97-105.

Prayag, G., Hosany, S., Muskat, B., \& Chiappa, D. G. (2017). Understanding the relationships between tourists' emotional experiences, perceived overall image, satisfaction and intention to recommend. Journal of Travel Research, 56(1), 41-54.

Qu, H. ve Li, I. (1997), The characteritics and satisfaction of Mainland Chinese visitors to Hong Kong. Journal of Travel Research, 35, 37-41.

Schmitt, B. (1999). Experiental marketing: a new framework for design and communications. Design Management Journal, 10(2), 10-16.

Seçilmiş, C. (2012), Termal turizm destinasyonlarından duyulan memnuniyet düzeyinin tekrar ziyaret niyetine etkisi: “Sakarı1lıca Örneği”. Elektronik Sosyal Bilimler Dergisi, 11(39), 231-250.

Sirakaya, E. ve Woodside, A. (2005). Building and testing theories of decision making by travellers. Tourism Management, 26(6), 815-832.

Tabachnick, G. B. \& Fidell, S. L. (2013). Using multivariate statistics. Boston: Pearson.

Taşkıran, Ö. ve Kızılırmak, İ. (2019). Deneyimsel pazarlama kapsamında sanal turların müze ziyaretlerine etkisi: Panaroma 1453 örneği. Uygulamalı Sosyal Bilimler Dergisi, 3(1), 1-19.

Tosun, C. ve Jenkins, C. (1996). Regional planning approaches to tourism development: the case of Turkey. Tourism Management, 17(7), 519-531.

Türk Dil Kurumu (TDK) (2020). Destinasyon. [URL: https://sozluk.gov.tr] (Erişim 05 Ocak 2020).

Ural, A., \& Kılıç, İ. (2005). Bilimsel Araştırma Süreci ve SPSS ile Veri Analizi. Ankara: Detay Yayınc1lik. 
Ünlüönen, K. ve Tokmak, C. (2009). Topkapı Sarayı'nda çalışanlar ve ziyaretçilerin sosyal taşıma kapasitesine göre değerlendirilmesi. İşletme Araştırmaları Dergisi, 1(1), 17-30.

Wang, Y. Feng, Y., \& Feng, B. (2013). The study on the significance of difference between demographics and tourist experience in Macau Casino Hotels. Eastren Academic Forum, 284287.

Williams, A. (2006). Tourism and hospitality marketing: fantasy, feeling and fun. International Journal of Contemporary Hospitality Management, 8(6), 482-495.

Yetiş Ardıç, Ş. (2015). Termal otel işletmelerinde deneyimsel pazarlama yaklaşımı. KMÜ Sosyal ve Ekonomik Araştırmalar Dergisi, 17(29), 90-98.

Yoon, Y. ve Uysal, M. (2005). An examination of the effects of motivation and satisfaction on destination loyalty: an structural model. Tourism Management, 26(1), 45-56.

EK 1: Araştırma Anketi

\begin{tabular}{|c|c|c|c|c|c|}
\hline \multicolumn{6}{|l|}{ Demografik İfadeler } \\
\hline \multicolumn{6}{|l|}{$\begin{array}{l}\text { 1. Cinsiyetiniz? } \\
\text { 2. Medeni Durumunuz? }\end{array}$} \\
\hline \multirow{2}{*}{\multicolumn{6}{|c|}{ 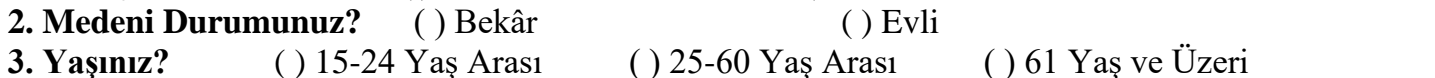 }} \\
\hline & & & & & \\
\hline \multicolumn{6}{|c|}{ 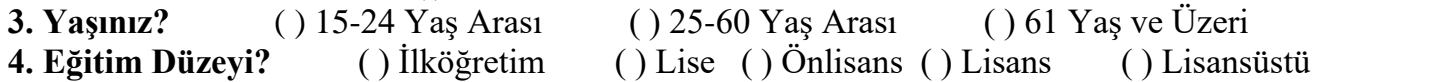 } \\
\hline \multirow{3}{*}{\multicolumn{6}{|c|}{ 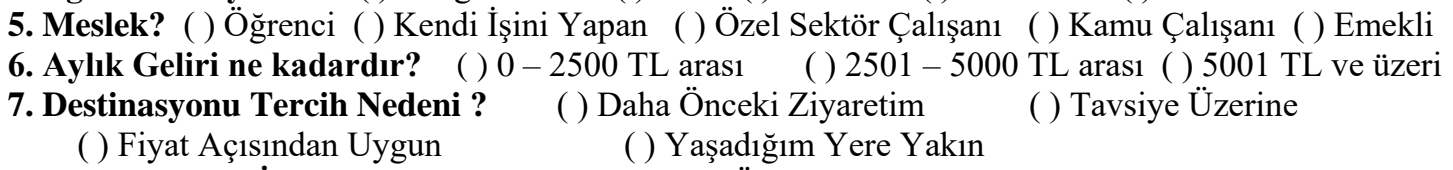 }} \\
\hline & & & & & \\
\hline & & & & & \\
\hline \multirow{2}{*}{\multicolumn{6}{|c|}{$\begin{array}{l}\text { 8. Destinasyonla İlgili Bilgi Kaynakları? () Daha Önceki Ziyaretim ( )Seyahat Acentası } \\
\begin{array}{ll}\text { () Sosval Medva-İnternet } & \text { () Arkadas Cevresi }\end{array}\end{array}$}} \\
\hline & & & & & \\
\hline \multicolumn{6}{|c|}{ 9. Tatilini Birlikte Geçirdiğin Kişiler? ( ) Yalnızım ( ) Eşimle ( ) Eşim ve Çocuklarımla } \\
\hline \multicolumn{6}{|c|}{ () Ailemle (Ebeveynler) () Kız-Erkek Arkadaşımla $\quad$ () Arkadaş Grubumla } \\
\hline \multirow{2}{*}{\multicolumn{6}{|c|}{$\begin{array}{l}\text { 10. Destinasyona Geliş Şekli? () Münferit () Paket Tur } \\
\text { 11. Genel Memnuniyet Düzeyi? () Evet () Hayır }\end{array}$}} \\
\hline & & & & & \\
\hline \multicolumn{6}{|l|}{$\begin{array}{l}\text { 12. Tekrar Ziyaret Niyeti? } \\
\text { Sayın Katılımcı; asă̆ıda ver alan ifadelerle ilgili düsünceleriniz }\end{array}$} \\
\hline \multirow{2}{*}{\multicolumn{6}{|c|}{$\begin{array}{l}\text { Katılıyorum (3) Kararsızım (2) Katılmıyorum (1) Kesinlikle Katılmıyorum şeklinde belirtiniz. } \\
\text { If }\end{array}$}} \\
\hline & & & & & \\
\hline Turistik çalışanlarla iyi iletişim kurdum. & $\underline{5}$ & 4 & $\underline{3}$ & 2 & 1 \\
\hline Yerel halk ile iyi iletişim kurdum. & $\underline{5}$ & $\underline{4}$ & $\underline{3}$ & 2 & $\underline{1}$ \\
\hline Emniyet ve güvenlik yeterlidir. & $\underline{\underline{5}}$ & 4 & $\underline{3}$ & $\underline{2}$ & 1 \\
\hline Yüksek kalitede hizmet aldım. & $\underline{5}$ & $\underline{4}$ & $\underline{3}$ & $\underline{2}$ & $\underline{1}$ \\
\hline Çevre genel olarak temizdi. & $\underline{5}$ & $\underline{4}$ & $\underline{3}$ & $\underline{2}$ & 1 \\
\hline Seyahatim esnasında hava çok güzeldi. & $\underline{\underline{5}}$ & 4 & $\underline{3}$ & 2 & 1 \\
\hline Eşsiz turizm kaynaklarına sahiptir. & $\underline{5}$ & 4 & $\underline{3}$ & 2 & 1 \\
\hline Konaklama yerleri kalitelidir. & $\underline{5}$ & $\underline{4}$ & $\underline{3}$ & $\underline{2}$ & $\underline{1}$ \\
\hline Yiyecek içecek yerleri kalitelidir. & $\underline{5}$ & $\underline{4}$ & $\underline{3}$ & $\underline{2}$ & 1 \\
\hline Turistik fiyatlar genel olarak uygundu. & $\underline{5}$ & $\underline{4}$ & $\underline{3}$ & $\underline{2}$ & $\underline{1}$ \\
\hline Seyahati planlarken bilgilere ulaşmam kolay oldu. & $\overline{5}$ & $\underline{4}$ & $\underline{3}$ & $\underline{2}$ & $\underline{1}$ \\
\hline Seyahati planlarken uzmanlardan yüksek kalitede hizmet aldım. & $\underline{\overline{5}}$ & $\underline{4}$ & $\underline{3}$ & $\underline{2}$ & $\underline{1}$ \\
\hline Seyahati planlamak için çok zaman harcadım. & $\underline{5}$ & $\underline{4}$ & $\underline{3}$ & $\underline{2}$ & $\underline{1}$ \\
\hline Seyahati planlarken destinasyonla ilgili çok bilgi buldum. & $\overline{5}$ & $\underline{4}$ & $\underline{3}$ & $\underline{2}$ & $\underline{1}$ \\
\hline Destinasyonda yönlendirici bilgiler yeterlidir. & $\underline{5}$ & $\underline{4}$ & $\underline{3}$ & $\underline{2}$ & $\underline{1}$ \\
\hline Destinasyonda genel olarak çok şey öğrendim. & $\underline{5}$ & $\underline{4}$ & $\underline{3}$ & $\underline{2}$ & $\underline{1}$ \\
\hline Destinasyonda öğrendiklerim beni daha fazla öğrenmeye teşvik etti. & $\underline{5}$ & $\overline{4}$ & $\underline{3}$ & $\underline{2}$ & 1 \\
\hline Seyahat hazırlıkları esnasında hiçbir problemle karşılaşmadım. & $\underline{5}$ & $\underline{4}$ & $\underline{3}$ & $\underline{2}$ & $\underline{1}$ \\
\hline
\end{tabular}




\begin{tabular}{|l|c|c|c|c|c|}
\hline Seyahatin fiyatını uygun buldum. & $\underline{5}$ & $\underline{4}$ & $\underline{3}$ & $\underline{2}$ & $\underline{1}$ \\
\hline Destinasyonda çok çeşitli aktiviteler yapılabilmektedir. & $\underline{5}$ & $\underline{4}$ & $\underline{3}$ & $\underline{2}$ & $\underline{1}$ \\
\hline Destinasyonda seçim yapılabilecek kadar aktivite bulunmaktadır. & $\underline{5}$ & $\underline{4}$ & $\underline{3}$ & $\underline{2}$ & $\underline{1}$ \\
\hline Destinasyonda çok eğlendim. & $\underline{5}$ & $\underline{4}$ & $\underline{3}$ & $\underline{2}$ & $\underline{1}$ \\
\hline Destinasyonun yerleşimi duyularıma haz verdi. & $\underline{5}$ & $\underline{4}$ & $\underline{3}$ & $\underline{2}$ & $\underline{1}$ \\
\hline Destinasyon çok etkileyici bir yerdi. & $\underline{5}$ & $\underline{4}$ & $\underline{3}$ & $\underline{2}$ & $\underline{1}$ \\
\hline Destinasyon aktivitelerini takip ederek hoş vakit geçirdim. & $\underline{5}$ & $\underline{4}$ & $\underline{3}$ & $\underline{2}$ & $\underline{1}$ \\
\hline Destinasyon aktivitelerini takip ederek çok eğlendim. & $\underline{5}$ & $\underline{4}$ & $\underline{3}$ & $\underline{2}$ & $\underline{1}$ \\
\hline Destinasyonda kendimi farklı bir zamanda/mekândaymış gibi hissettim. & $\underline{5}$ & $\underline{4}$ & $\underline{3}$ & $\underline{2}$ & $\underline{1}$ \\
\hline Destinasyonda kendimi gerçek yaşamdan tamamen uzaklaşmış hissettim. & $\underline{5}$ & $\underline{4}$ & $\underline{3}$ & $\underline{2}$ & $\underline{1}$ \\
\hline Destinasyonda kendimi farklı bir karakter olarak hissettim. & $\underline{5}$ & $\underline{4}$ & $\underline{3}$ & $\underline{2}$ & $\underline{1}$ \\
\hline Destinasyonda gerçek bir ahenk hissettim. & $\underline{5}$ & $\underline{4}$ & $\underline{3}$ & $\underline{2}$ & $\underline{1}$ \\
\hline Destinasyonda olmak çok zevkliydi. & $\underline{5}$ & $\underline{4}$ & $\underline{3}$ & $\underline{2}$ & $\underline{1}$ \\
\hline
\end{tabular}

